\begin{tabular}{r}
\hline \hline \\
811.163 .41 '373.1:003.035 \\
811.521 373.1:003.035 \\
https://doi.org/10.18485/mks_srpska_slavistika.2018.1.ch13
\end{tabular}

\author{
Љиљана Р. МАРКОВИЋ \\ Универзитет у Београду \\ Филолошки факултет \\ Катедра за оријенталистику \\ Група за јапански језик и књижевност
}

\title{
ТРАНСКРИПЦИЈА И АДАПТАЦИЈА ИМЕНА ИЗ ЈАПАНСКОГ У СРПСКИ И РУСКИ ЈЕЗИК
}

\begin{abstract}
С обзиром на висок степен компатибилности фонолошких система јапанског и српског језика, не очекују се у српским текстовима ендогени транскрипцијски проблеми при навођењу јапанских имена. Ипак, због посредованих превода јапанских текстова са енглеског, француског, немачког и руског језика ови проблеми се у континуитету појављују.

У раду се предлаже транскрипцијски образац који је погоднији за српски језик, са јапанским гласовима приказаним уз помоћ јапанских службено предложених научних транскрипцијских вредности уместо оригиналних јапанских писаних симбола. Транскрипцијски образац, уколико би био прихваћен у научној и широј јавности, водио би ка правилности и једнозначности у области јапанске ономастике и њене такозване широке транскрипције (и у масовним медијима, на пример).

Кључне речи: јапански језик, српски језик, руски језик, транскрипција, јапанска топонимика, властита имена.
\end{abstract}

\section{I. Уводне напомене}

Предмет обављеног истраживања био је постављање одговарајућег система широке транскрипције јапанске топонимике, антропонимике и патронимике на српском, и анализа владајуће праксе на руском говорном подручју, имајући у виду да руска пракса постаје све значајнији узор за анализу, пре свега, због све већег броја радова из области јапанологије који се публикују на руском говорном подручју.

Обрађени материјал састоји се од корпуса који обухвата: 198 картица које садрже ономастичке лексичке јединице, 130 картица које садрже топонимичке јединице и 8 картица које садрже асимилиране позајмљенице и неке друге јапанске апелативе, као и одређен број одговарајућих лексичких јединица из литературе, штампе,

*1jiljana.markovic@gmail.com 
радија и телевизије које је аутор сам припремио. Што се тиче транслитерације јапанских ономастичких термина у руски, проанализирано је 457 јединица позајмљених из јапанског језика у руски, класификованих у 13 предметно-тематских целина: лексика из сфере уметности (50), домаћинства (45), спортска лексика (92), називи државних установа, здања, дужности (14), кухиња (90), медицинска лексика (5), елементи говорног бонтона (15), називи традиционалних религија и веровања (37), називи природних појава, биљака и климатских особености (12), називи новчаних јединица и јединица мера (9), називи разних видова транспорта (14), јапанска властита имена, аниме, манга (74).

Циљ овог истраживања био је да се омогући давање предлога за функционално задовољавајући систем широке транскрипције јапанске ономастике, како би се она што је могуће тачније приказивала с обзиром на фонетске и графијске могућности српског и руског језика, и то на целом подручју, како географском, тако и у различитим сферама употребе српског језика, као и руског језика, једнообразно и без неоправданих одступања. Резултат спроведеног истраживања је радни предлог важног и сложеног научноистраживачког подухвата.

\section{II. Фонолошки систем јапанског језика у односу на српски и руски језик}

\section{1. Особености јапанског фонолошког система}

Услед одређених језичких карактеристика које јапански језик чине тешко одредивим одувек је међу лингивистима постојало неслагање о пореклу јапанског језика. Тако је јапански језик сврставан не само међу алтајске већ и међу малајско-полинезијске језике. Једно од најутицајнијих мишљења о овој теми ван Јапана дошло је од америчког лингвисте Р. А. Милера, који заступа тезу да је јапански језик алтајски, с тим што је сродан прото-источноалтајском, који се, по свој прилици, био поделио на прото-северноалтајски и полуострвско алтајски, отприлике у доба неолита. Р. А. Милер, даље, сматра да, док су манџурско тунгуски језици главни језички потомци прото-северноалтајског, јапански и корејски представљају језике који су се развили из прото-полуострвског алтајског, који се био поделио на протополуострвски (данашњи главни представник му је корејски) и прото-острвски, из којег се развио старојапански (Miller 1980: 50).

Према мишљењу водећих данашњих јапанских лингвиста, који се служе, поред лингвистичког, и најширим антрополошким и етнолошким приступом, јапански језик по својим битним типолошким особинама представља језик такозване алтајске језичке породице, при чему је до стварања старојапанског јазика дошло стапањем алтајског језика, који су са собом донели миграцијом таласи из Јужне Кореје, са полинежанским језиком староседелаца јапанских острва. Како су дошљаци, који су говорили алтајским језиком, били на вишем техничком и културном нивоу од староседелаца, удео њиховог језика у одређивању морфолошког и синтаксичког профила старојапанског био је такође доминантан. Језик староседелаца је, ипак, добрим делом у старојапанском оставио своје лексичко и фонолошко полинежанско наслеђе. 
Фонолошки систем овако оформљеног јапанског језика релативно је једноставан. Вокалски систем сачињава пет вокала: $\boldsymbol{a}, \boldsymbol{u}, \boldsymbol{y}, \boldsymbol{e}, \boldsymbol{o}$, који могу бити кратки и дуги. Дуги вокал је по природи исти као и његов кратак пар, с тим што му је дужина отприлике два пута већа од дужине кратког вокала. Дужине вокала важне су у јапанском језику јер, наравно, значења лексема неретко стоје у зависности од дужине вокала (Đimbo 1947: 20).

Консонантски систем састоји се од петнаест сугласника, а то су у јапанској

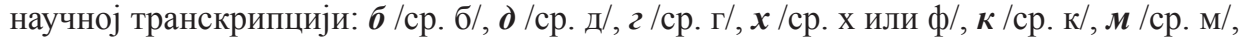

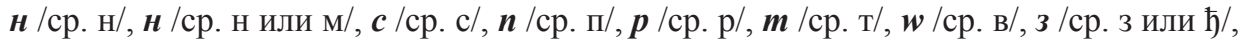
$\boldsymbol{y} / \mathrm{cp} . \mathrm{j} /$. Сви ови консонанти имају различите вредности у зависности од тога који вокали им претходе или стоје иза њих. Важније варијације уочавамо код следећих сугласника:

$\boldsymbol{h}$ - испред вокала $\boldsymbol{a}, \boldsymbol{e}, \boldsymbol{u}, \boldsymbol{o}$ изговара се као српско $\boldsymbol{x}$. Међутим, када $\boldsymbol{x}$ стоји испред вокала $\boldsymbol{y}$, изговара се тако што се кроз кружно формиране усне издахне ваздух, слично као српско $\boldsymbol{\phi}$, с тим што горњи секутићи не додирују доњу усну и што се ни саме заокружене усне не додирују приликом изговора. (У руском језику изговара се као у речи «соха»). ( Японский разговорник и словарь 2003:15).

$\boldsymbol{\mu}$ - када стоји на крају речи, или испред $\boldsymbol{y}$ (ипсилон), $\boldsymbol{w}$ (дупло ве), $\boldsymbol{p}, \boldsymbol{c}, 3, \boldsymbol{x}$, или испред вокала звучи као $\dot{\eta}$ у међународној транскрипцији. На крају речи изговара се као носни звук. Средњи део језика подиже се ка тврдом непцу.

- Испред $\boldsymbol{n}, \boldsymbol{\sigma}$ и $\boldsymbol{M}$ звучи као српско $\boldsymbol{M}$. (У руском језику изговара се као у речи «самба») (Японский для начинающих 2011: 30).

- Испред $\boldsymbol{m}, \boldsymbol{\partial}, \boldsymbol{c}, \boldsymbol{\mu}$ и $з$ звучи као српско $\boldsymbol{H}$.

Пред самогласником по звуку личи на руско тврдо $\boldsymbol{\boldsymbol { \mu }}$. (Японский разговорник и словарь 2003: 17) $\boldsymbol{H}$ се поред ових варијација увек изговара тако да је назални пролаз отворен, узимајући пуно време које одговара слогу у јапанском језику. (У руском језику изговара се као у речи «нора») (Японский разговорник и словарь 2003: 17).

$\boldsymbol{c}$ - испред вокала $\boldsymbol{a}, \boldsymbol{e}, \boldsymbol{u}, \boldsymbol{o}$ изговара се као српско $\boldsymbol{c}$. (У руском језику изговара се као у речи «сам» (Японский для начинающих 2011: 30) Испред вокала $\boldsymbol{u}$ изговара се као палатализовано $\boldsymbol{m}$ (шекира) у неким нашим дијалектима. Разликује се од руског $\boldsymbol{c}$ уколико стоји испред самогласника $\boldsymbol{u}$. Подсећа на меки шиштећи звук, средњи између руског «щ» и «с». Не сме се мешати ни са једним из ових звукова (Японский разговорник и словарь 2003: 18).

$\boldsymbol{m}$ - испред вокала $\mathbf{a}, \boldsymbol{e}, \boldsymbol{o}$ изговара се као српско $\boldsymbol{m}$. (У руском језику изговара се као у речи «танк») (Японский для начинающих 2011: 31).

- Испред вокала $\boldsymbol{u}$ изговара се као у српском језику.

Испред самогласника «и» подсећа на звук, средњи између руског «Т» и «ч». Не сме се мешати ни са једним од ових звукова (Японский разговорник и словарь 2003: 18).

- $\quad$ Испред вокала $\boldsymbol{u}$ изговара се као српско с.

Испред самогласника «у» звучи као руско «ц» (Японский разговорник и словарь 2003: 19).

3 - испред вокала $\boldsymbol{a}, \boldsymbol{e}, \boldsymbol{o}$ и изговара се као српско 3.

Испред вокала $\boldsymbol{u}$ изговара се као српско $\boldsymbol{\eta}$. 
Изговара се као спојено «д» и «з» - «дз» (Японский для начинающих 2011: 31). $\mathbf{w}$ - као у српском $\boldsymbol{в}$, само што доња усна не додирује горње секутиће.

Изговара се удахом између затворених усана. Добија се звук, средњи између руског «в» и «у» (Японский разговорник и словарь: 2003). (У руском језику изговара се као у речи «ванна») (Японский для начинающих 2011: 31).

$\boldsymbol{r}$ - полутан између српског $\boldsymbol{p}$ и српског л. Сугласници $\boldsymbol{\kappa}, \boldsymbol{n}, \boldsymbol{c}, \boldsymbol{m}$ и $\boldsymbol{\boldsymbol { H }}$ често су удвојени. Разликују се од руског «р». Врх језика додирује зубе. Добија се звук, средњи између «л», «р» и «л». Нешто средње између «р», «л» и «д» - «рама» «лама» «дама» (Японский для начинающих 2011: 32).

Најважнија одлика фонетске структуре јапанског језика је у томе што се консонанти појављују искључиво у саставу консонантско-вокалске групе, тако да никада нису у позицији на њеном крају с изузетком консонаната. Овакве слоговне групе (сугласник + самогласник) могу бити просте и сложене. Просте су када један од пет вокала стоји непосредно иза консонанта, а сложене су ако између консонанта и вокала стоји глас $\boldsymbol{y}$ (српски - j), који умекшава консонант иза којег стоји и, у принципу, се изговара. Тако добијамо следеће просте и сложене слогове.

Кунреи транскрипција:

\begin{tabular}{|c|c|c|c|}
\hline прости & сложени & српски језик & руски језик \\
\hline ka ki ku ke ko & kya kyu kyo & ка, ки, ку & ка ки ку кэ ко, кя кю кё \\
\hline sa si su se so & sya syu syo & ша, ши, шу & са си ису сэ со, ся сю сё \\
\hline ta ti tu te to & tya tyu tyo & та, ти, ту & та ти ту тэ то, тя тю тё \\
\hline ma ni nu ne no & nya nyu nyo & ма, ни, ну, не, но & ма ни ну нэ но, ня ню нё \\
\hline ma mi mu me imo & mya myu myo & ма, ми, му, ме & ма ми му мэ имо, мя мю мё \\
\hline уа-уu-уо & --- & ja, jy, jo & я- Ю- ё \\
\hline ra ri ru re to & rya ryu ryo & ра, ри, ру, ре & ра ри ру рэ ро, ря рю рё \\
\hline wa --- wo & --- & ва, во & ва - во \\
\hline ga gi gu ge go & gya gyu gyo & га, ги, гу, ге, го & га ги гу гэ го, гя гю гё \\
\hline za zi zu de do & zya zyu zyo & за, зи, зу, де, до & $\begin{array}{l}\text { дза дзи дзу дзэ дзо, дзя дзю } \\
\text { дзё }\end{array}$ \\
\hline da zi zu de do & --- & да, зи, зу, де, до & да дзи дзу дэ до \\
\hline \multirow[t]{2}{*}{ ba bi bu be bo } & bya byu byo & ба, би, бу, бе, бо & ба би бу бэ бо, бя бю бё \\
\hline & pya pyu pyo & & \\
\hline pa pi pu pe po & & па, пи, пу, пе, по & па пи пу пэ по, пя пю пё \\
\hline
\end{tabular}

Сваки слог у јапанском језику има исту дужину и исти нагласак. Акцентуација je у јапанском језику заснована на висини (гласовној), а не на нагласку. Гласовна висина представља релативну звучну висину сваког слога. Обично стоји разлика између звучне висине првог и другог слога код сваке речи. Пошто у српском језику 
није нужно обележавање акцента у писаној речи, и пошто правописна проблематика не би, уопштено говорећи, требало да обухвата и проблеме акценатске природе у језицима у којима нема обавезног обележавања акцента или таквог обележавања уопште нема, а такав је и јапански језик, сматрамо да се код разматрања широке транскрипције јапанске ономастике на подручју српског језика проблематика акцентуације може занемарити (Stanić 1973: 10).

Бројни и веома занимљиви социолингвистички аспекти језичке ситуације у Јапану не могу се сматрати фактором који утиче на изговорну вредност јапанске ономастике, као што на њену изговорну вредност ни дијалекатске или диглосијске појаве не врше приметнији утицај (Miller 1980: 141-172).

Сматрамо да, с обзиром на изнето, при изради широке транскрипције јапанских имена не би требало да буде озбиљнијих потешкоћа. Прилагођавајући фонолошку грађу јапанског фонолошким особинама нашег језика, код поменуте широке транскрипције препоручили бисмо да се: сви консонанти транскрибују искључиво у складу са њиховом изворном фонолошком вредношћу ( $\boldsymbol{x}$ испред $\mathbf{y}$ као српско $\boldsymbol{\phi}$, на пример, Фукуока; з испред $\boldsymbol{u}$ као српско $\boldsymbol{\eta}$, на пример, планина Фуђи; да се не дају дужине вокала; да се не обележавају геминати код вокала).

\section{2. Могућност израде транскрипџионе схеме}

Све чешће у преведеној и специјализованој литератури, научним радовима и коментарима у књигама сусрећу се речи и термини позајмљени из јапанског језика, али се они у речницима не помињу или не присуствују у значајној мери. Не улазећи у сам садржај одређене публикације, може се приметити да њих све обједињује потпун неред у делу ортографије при транслитерацији, тј. при преносу слово по слово путем руске азбуке (ћирилице) јапанских речи. У вези са тим потребно је посебно нагласити да се јапански језик јавља другим (после западноевропских језика) извором сталног попуњавања фонда термина. Нажалост, међу свим тим речима и терминима може се приметити велики проценат очигледно погрешних транскрипционих варијанти, које су карактеристичне у основи за руску транскрипцију јапанских речи, и без нарочитог обраћања пажње на јапански оригинал, већ на ромађи систем транслитерације јапанских речи на латиницу. Био то нови систем кунреј или стари, унеколико различити хепберновски систем, грешке ће се понављати (Прошина 2007: 100-101).

Садржај и разнообразност транскрипционих варијанти термина захтева известан напор за њихову нормализацију, не само од стране специјалиста у области лексикографије већ и преводилаца, аутора књига и чланака. Сложеност формирања јасне и научно засноване терминологије условљена је тиме што она зависи од тога коликим знањем и терминологијом владају аутори и преводиоци тог језика на ком су били предложени и уведени у употребу дати термини (Сердюченко 1967: 222).

Узимајући у обзир то што ортографија позајмљених термина из јапанског језика није регулисана у стандардима и рекомендацијама ИСО, сваки аутор који у свом раду користи запис термина ослања се само на своје лично искуство и знање. Тако, на пример, ознака речи каидзен путем јапанског писма изгледа: 改善, у транскрипцији ромађи - каизен. Ознака датог термина може се наћи у бројним књигама 
и чланцима из разних области, при чему се обавезно појављују разлике у запису, а изабрати један из неколико термина често представља проблем. Приказ каизен у руској транскрипцији као кайдзен, кайзен или чак кайцен одражава нетачно писање тог термина и води ка неправилном изговору и кварењу фонетике јапанског језика (Сердюченко 1967: 223). Погрешна транскрипција термина, чији је превод узет из америчких извора или позајмљен од аутора из књига и чланака, по правилу је настала после превода и користи се његовом оригиналном фонетиком и записом речи, а не преводима са других језика.

Разлика транскрипција између хепберновске и такозваног система кунреј-ромађи (буквално преведено: директни ромађи, традиционални руски превод: државна латиница) прилично је велика: на пример, реч суси (јапанско село) пише се сусхи по Хепберну и суси по кунреј-ромађи систему. Та реч је дошла и у руски језик у американизованом виду по Хепберну: сусхи. Одатле и несвојствено писање јапанских речи ћирилицом (термини, географски појмови, властита имена итд.), ако су они позајмљени из текстова преведених на енглески. Ово делом произилази из лошег знања правила транскрипције, а за резултат има различите транскрипције, изузимајући хепберновски и кунреј-ромађи систем, што доводи до забуне. На пример, реч која се у савременом руском језику изговара као гемба и у систему Хепберна као гемба, у систему кунреј-сики изговара се као генба (Сердюченко 1967: 224).

Најчешће се кунреј-ромађи системом користе носиоци јапанског језика и лингвисти који изучавају јапански. Основна предност система кунреј-ромађи своди се на то што он логичније преноси граматику јапанског језика у односу на систем Хепберна. Хепберновски систем је распрострањенији. На основу њега обично се дешава позајмљивање из јапанског језика у западноевропске, а понекад и у руски језик, при чему оно не долази директно из јапанског језика, већ преко енглеског. Упоредите имена која се често срећу, као што су: Хитаћи, Тошиба (имена компанија), термин хадзимэ (започните), који се користи у џудоу и каратеу, са својим нормативима Хитати, Тосиба, хадзимэ (Сердюченко 1967: 224). У традиционалној транслитерацији јапанског језика у руски ређе се користе транслитерација Јевгенија Генриховича Спаљвина (1900) и чешће - Јевгенија Дмитријевича Поливанова (1917). Такође се узима у обзир и транслитерација Дмитрија Матвејевича Позднејева, предложена 1907. године, али она је широко распрострањена. Могуће је израдити и следећу транскрипциону схему за примену транскрипције у штампи, лексикографији, радију и телевизији. Служили смо се схемом предложеном од стране Института за језик и књижевност у Сарајеву. За сваки јапански самогласник дали смо по један изворни знак, а такође и предложену вредност у српској транскрипцији. Код јапанских сугласника за сваки изворни слоговни знак који почиње датим консонантом дали смо транскрипцијску вредност тог консонанта. Овај поступак је приказан на следећим схемама: 
Схема 1. Прости консонантско-вокалски слогови: јапански вокали = српски вокали (а, и, о, е, о)

\begin{tabular}{|c|c|c|}
\hline $\begin{array}{l}\text { јапански } \\
\text { консонант }\end{array}$ & $\begin{array}{c}\text { српска транкрипција } \\
\text { вредности слога }\end{array}$ & руски језик \\
\hline $\mathrm{k} / \mathrm{g}$ & ka ki ku ke ko ga gi gu ge go & ка ки ку кэ ко, га ги гу гэ го \\
\hline $\mathrm{s} / \mathrm{z}$ & sa ši su se si za đi zu ze zo & са си су сэ со, дза дзи дзу дзэ дэо \\
\hline$t / d$ & ta ćicu te to da đi zu ze zo & та ти цу тэ то, да дзи дзу дэ до \\
\hline $\mathrm{n}$ & na ni nu ne no ba bi bu be bo & на ни ну нэ но, ба би бу бэ бо \\
\hline $\mathrm{h} / \mathrm{p}, \mathrm{b}$ & ha hi fu he ho----------pa pi pu pe po & ха хи фу хэ хо, па пи пу пэ по \\
\hline $\mathrm{m}$ & ma mi mu me mo & ма ми му мэ мо \\
\hline $\mathrm{y}$ & $\mathrm{Ja}-\mathrm{ju}-\mathrm{jo}$ & я юе ё \\
\hline $\mathrm{r}$ & Ra ri ru re ro & ра ри ру рэ ро \\
\hline $\mathrm{w}$ & Va - - - vo (ili o) & ва (о) \\
\hline $\mathrm{n}$ & ---- & H \\
\hline
\end{tabular}

Схема 2. Сложени консонантско-вокалски слогови

\begin{tabular}{|l|l|l|}
\hline $\begin{array}{c}\text { јапански } \\
\text { консонант }\end{array}$ & \multicolumn{1}{|c|}{ српска транкрипичја вредности слога } & \multicolumn{1}{|c|}{ руски језик } \\
\hline $\mathrm{k} / \mathrm{g}$ & kja kju kjo gja gju gjo & кя кю кё, гя гю гё \\
\hline $\mathrm{s} / \mathrm{z}$ & ša šu šo đa đu đo & ся сю сё, дзя дзю дзё \\
\hline $\mathrm{t} / \mathrm{d}$ & ća ću ćo da dju do & тя тю тё, дзя дзю дзё \\
\hline $\mathrm{n}$ & nja nju njo & ня ню нё \\
\hline $\mathrm{h} / \mathrm{p}, \mathrm{b}$ & hja hju hjo -------------pja pju pjop bja bju bjo & хя хю хё, пя пю пё, ня ню нё \\
\hline $\mathrm{m}$ & mja mju mjo & мя мю мё \\
\hline $\mathrm{r}$ & rja rju rjo & ря рю рё \\
\hline
\end{tabular}




\section{III. Проблеми адаптације имена из јапанског језика у српском и руском језику}

\section{1. Историјски осврт}

Јапанска имена у наш језик улазила су готово искључиво преко неког од светских језика. Тако су и настале карактеристичне грешке - рецимо топоними Чиба, Кочи, Хитачи и др. Долазећи преко енглеског, од енглеског транскрипционог $\boldsymbol{c h}$ за јапанско $\boldsymbol{\hbar}$, нама су дали $\boldsymbol{u}$ уместо $\boldsymbol{\hbar}$. Значи, специфичност енглеског језика који не познаје $\boldsymbol{h}$ већ само $\boldsymbol{u}(\boldsymbol{c h})$ транспоновала је у наше језичко подручје, које веома јасно разликује $\boldsymbol{\varphi}$ од $\boldsymbol{\hbar}$, једну сасвим непотребну грешку. Исти је такав случај и са енглеским транскрипционим $\boldsymbol{\mu}$ (у топонимима као што су Фуџијама, Фуџиока и сл.). Опет, енглески језик не познаје звук тако мек као што је јапанско и српско ђ (у енглеским изворницима транскрибовано као $\boldsymbol{j}$ (џ), па смо ми тако, нажалост, дошли до Фуџијама уместо Фуђијама, Фуџиока уместо Фуђиока (Rodić 1976: 146-149).

Имена која су долазила посредством француског транскрипционог подручја имају тенденцију ка конфузији на релацији $\boldsymbol{\hbar}$ и $\boldsymbol{\boldsymbol { m }}$. Односно, $\boldsymbol{c h}$ које у француском језику представља звук $\boldsymbol{w}$, неки наши извори протумачили су као $\boldsymbol{u}$, што би било $\boldsymbol{u} \boldsymbol{x}$ да долази са енглеског транскрипционог подручја.

Имена која су дошла посредством руског транскрипционог подручја, услед погрешног интерпретирања и недовољног познавања правила руске ћириличне фонетске транскрипције јапанског језика, често на крају уместо $\boldsymbol{u}$ имају српско $\boldsymbol{j}$ (на пример: Сендај уместо Сендаи, услед руског Сэндай).

Оскудна језичка спознаја довела је до тога да одређен географски појам улази у састав имена топонима, те је сада, на пример, Фуџијама на нашем говорном подручју прихваћено целокупно као топоним, тако да срећемо: „Планина Фуђијама ...” Јама на јапанском језику значи планина, па би требало писати „планина Фуђи”. Или у примеру „река Сумидагава”, при чему је кава на јапанском језику река (к прелази у г), требало би писати „река Сумида”. Или, Meiji Tenno - Mutsuhito. Meiđi Tennô значи Цар Меиђи (tennô - цар), а његово лично име било је Муиухито, или Циму Тенно - Цар Ђиму (JLZ 610, PP е, Bor. е., Bel. e, ELZ 298; JLZ 424, ELZ 29).

Како се јапанске позајмљенице представљају на ћириличном писму, то можемо говорити о њиховој делимичној писменој асимилацији. Током свог развића, 62 речи у руском језику имале су неколико варијанти записа, који су на крају нестали само за половину речи, тј. дате позајмљенице до садашњег времена могу се оформити са више писаних варијанти. Међу основним узроцима варијација писменог фиксирања јапанских речи могу се навести следећи:

1. употреба различитих система приликом транскрипције позајмљеница,

2. посредни пут позајмљивања, на пример реч „джиу-джицу” "'дзю-дзицу”/ „дзюдзицу” (вид јапанске борбе) позајмљена у руски језик из енглеског,

3. развој речи у руском језику, и као последица тога, јављање нових варијанти записа (Габдуллина 2012: 12-16). 


\section{2. Савремено стање (анализа ексиерпиране грађе)}

На основу прегледа корпуса, дошли смо до следећих закључака у вези са најчешћим грешкама које се јављају у нашој лексикографији при транскрибовању јапанске ономастике и јапанске лексике уопште.

Код картица које садрже антропонимијске и патронимијске јединице редовно се срећемо са следећим грешкама:

- $\quad \boldsymbol{u}$ уместо ந: Фуцивара но Садаје, јапански песник, (MEР 546x) уместо Фуђивара

- дз уместо ந: Токутоми Кендзиро, јапански књижевник, (ELZ 411x, MEP 398 с) уместо Токутоми Кенђиро

- $\quad \boldsymbol{m и}$ уместо ћu: Итикава Сеити, јапански револуционар, (MEP 743 c, JLZ 407, ELZ 216) уместо Ићикава Сеићи

Кокурд Гоитиро, јапански политички радник (ELZ 521) уместо Кокуре Гоићиро, Toкуда Куити, јапански политичар (ELZ 410x, MEP 398x) уместо Токуда Куићи

- $\quad \boldsymbol{4} \boldsymbol{x}$ уместо $\boldsymbol{\hbar}$ :Танака Гииихи, јапански политичар (ELZ 324 х) уместо Танака Гиићи

- $\quad \boldsymbol{u y}$ уместо $\boldsymbol{j}$ : Муро Киусо, јапански филозоф (МЕР 610 с) уместо Муро Kjyco

- $\quad$ тсу уместо цу: Коетсу, јапански сликар (JLZ 479, ELZ 571) уместо Коеиу

Када је реч о неким познатим именима као што је, на пример, јапански књижевник Нацуме Сосеки, он се у овим изворима појављује као Нацуме Сосеки, а не као Натсуме Сосеки, што нам јасно показује да се погрешна транскрипција јавља услед непознавања правила фонетског читања, стихијног мешања различитих транскрипцијских система и недоследности у њиховој селекцији. Горњи пример правилне транскрипције срећемо у МЕР 633 с. Јавља се, међутим, и погрешно Нацуме Созеки (Tanizaiki 1972: 689).

Код транскрибовања вокала код антропонимике и патронимике уочили смо следеће грешке:

- $\quad \boldsymbol{o}$ : да би изразили дужину вокала $\boldsymbol{o}$ даје се $O$ 'Куни, јапанска глумица (МЕР $716 \mathrm{x})$ уместо Окуни

- $\quad \boldsymbol{y}$ : Фоуијта, јапански сликар (JLZ 292, ELZ 426) уместо Фуђита. Очигледно, име је транскрибовано према француском писању (оу=y, $\mathrm{j}=$ ж) јер је у загради као упутство за читање дато Фужта

- $\quad \boldsymbol{e}$ : Кокуро, јапански политички радник (JLZ 480, ELZ 521) уместо Кокуре

- $\quad \boldsymbol{i}$ : Ихара Сајкаку, јапански књижевник (MEP 744x) уместо Ихара Саикаку. Дакле, $\boldsymbol{u}$ се транскрибује често са $\boldsymbol{j}$, поготово када долази преко руске транскрипције, услед тога што руско $\check{\boldsymbol{u}}$ бива транскрибовано са нашим j. Заједно са тим, супротно систему Поливанова, у руском језику може се ретко срести транслитерација са „и” уместо „й” (асикидо,, Саикаку).

- $\boldsymbol{a}$ : код транскрибовања овог вокала нема посебних одступања, сем што је у двема картицама у оквиру корпуса установљено, из неког разлога, да је $\boldsymbol{a}$ изостављено. Тако је у примерима Кобајши Такиии, јапански 
књижевник и Кобајши Масаки, јапански филмски редитељ (МЕР 263с), уместо Кобајаши. Слични случајеви изостављања слогова „а” не могу се наћи у руској транслитерацији.

У картицама које садрже топонимијске јединице редовно се срећемо са сличним грешкама, с тим што смо уочили и следеће:

- $\quad \boldsymbol{c x}$ уместо $\boldsymbol{m}$ : Схизуока, јапански град и назив покрајине (ELZ 698 a), уместо Шизуока

- $\quad \boldsymbol{u} x$ уместо $\boldsymbol{m}$ : Тсуихииа, јапанска острвска група (JLZ 1009), уместо Lуиима

- $\quad \boldsymbol{j}$ уместои $\boldsymbol{u}$ : Нијагата, град у Јапану (МЕР 663 с), уместо Ниигата, Сакај, град у Јапану (MEP 139 х), уместо Сакаи.

Занимљив је још и пример јапанског града Маебаши, који се јавља као Маебасхи (Мајебаши) (JLZ 576, ELZ 173, и као Мађебаши, MEP 454 с), а једино је исправно Маебаши. Из овога се може закључити да су лексикографи MEР-а, изгледа, мислећи да је читање Мајебаши дато у загради код примера из JLZ, не JLZ- ов покушај да да „фонетско” читање, већ да представи страни транскрипцијски облик (што је у овом случају, Маебасхи), па су читали енглеско транскрипцијско као српско $ђ$, те отуд имамо Мађебаши!

Од комплетно адаптираних јединица јапанске ономастике поменућемо само Јапан и Токио, где, због устаљеног и већ традиционалног начина употребе у нашој пракси, не предлажемо измене.

3.Однос савремене граматичке и правописне норме према адаптащији имена из јапанског језика у српском језику

Од досадашњих покушаја да се кодификује српска транскрипција јапанске ономастике, можемо извести:

1) Најопштија правила дата у члану 165. и 166. Правописа српскохрватског књижевног језика, издање Матице српске и Матице хрватске, Нови Сад, Загреб, 1960, која су исувише уопштена и сажета (односе се на имена - писање имена из свих живих станих језика уопште),

2) рад Правила и примери транскрипције јапанских географских имена (часопис Наш језик, Београд, 1976, XXXII/3, стр. 146-149). Док се у Правопису износе само нека важнија општа начела, у Правилима и примерима ... нису дата ни правила ни примери који би, са стручног становишта, могли да се сматрају целокупно задовољавајућим - то је, једноставно, био покушај да се до транскрипцијских правила дође са становишта сербокроатистичке правописне норме, јер тада у нас јапанологије као научне дисциплине још није било, па није било могуће да се до транскрипцијских правила дође на основу дијалога ова два стручна профила.

3) Правопис српског језика, издање Матице српске, Нови Сад, 2014. (поглавље XI. Прилагођено писање имена из страних живих језика - Транскрипција, стр. 171-250). 
Према типу завршетака, јапанске речи се деле на две основне групе, односно на речи са вокалним и консонантским завршетком. Управо, на крају речи може једино стајати консонант $\tilde{\boldsymbol{n}}$.

У случајевима када се реч завршава на консонант, такве речи се код нас уклапају у морфолошке промене које се примењују на наше именице мушког рода. У оквиру корпуса јавља се пример Рашомон, јапански редитељ (sic!) (JLZ 818). Рaшомон, је, иначе, име познатог јапанског филма Акире Куросаве, названог по делу јапанског писца Рјуносукеа Акутагаве, а Рашомон је назив једне од капија у древној јапанској престоници Кјоту.

Када се јапански топоними завршавају на ненаглашене вокале $\boldsymbol{o}$ и $\boldsymbol{a}$, предлажемо да се понашају као и наша имена са истим завршетком. На пример, Мито (град у Јапану) ген. Мита, дат. Миту, лок. Миту, и сл. Нико (излетиште и национални парк), Кјото, Кумамото (град на острву Кјушу) итд. Камакура (Камакуре, Камакури и сл). Осака, Фукуока, Асахикава, Мисава, Нара, Уеда итд. Топонимске називе са наглашеним y не би требало деклинирати (Хоншу, Кирју, Тенрју, Гоцу, Имазу, Мицу, Јаку, Кофу и сл).

Предлажемо да сва женска имена, која се углавном завршавају на $\boldsymbol{o}$, остају непромењена у деклинацији: Мићико, Маћико, Акико, Јурико, итд., пошто је реч о наглашеном вокалу . Исто тако би могла да се понашају и женска имена која се завршавају на неки други, иако ређе, вокал (Каору, Јасуми, Јура, Јуки, итд).

Што се, пак, тиче мушких имена, која се, углавном, завршавају на неки од вокала, предлажемо да се мењају као и наша имена: Јузо - Јузу, Јуза, Јузом итд., Масаки - Масакија, Масакију, Масакијем, Јасуши - Јасушија, Јасушију, Јасушијем, итд., Јошиаки - Јошиакија, Јошиакију, Јошиакијем, итд., Кунихиро - Кунихира, Кунихиру, Кунихиром, итд., Мунео - Мунеа, Мунеу, Мунеом, итд.

Код асимилираних позајмљеница, које су, наравно, малобројне, услед велике просторне удаљености и релативно слабо развијених економских, друштвених и културних веза, у смислу њихове прилагођености савременој граматичкој и правописној норми, такође нема посебних проблема. Тако се реч кимоно, врста јапанске народне ношње (MEP 234, EWLZ 465c), може, наравно, као позајмљеница мењати у складу са нашим граматичким променама: кимона, кимону, кимоном, итд. Исто је и са речју кендо која значи јапанско мачевање и борилачка вештина (ELZ 451 с). И ту реч можемо мењати: кенда, кенду, кендом, итд. Затим реч цудо, врста јапанске спортске вештине, метод за физичко и психичко васпитање (MEP 688 с, ELZ 182 b), која се мења: џуда, џуду, џудом, итд. Реч ииу-цииу, вештина самоодбране, блага уметност самоодбране супротно кен-цицу, оштрој уметности самоодбране (МЕР 687 c, ELZ 182 b) може се такође мењати: џиу-џице, џиу-џици, џиу-џицом, итд. Реч гејша, јапанска артисткиња, плесачица и певачица у чајџиницама и забавиштима (MEP 403 a, ELZ 506 b), такође: гејше, гејши, гејшом, итд. Затим, реч самурај, јапански витез, војнички племић (MEP 146 с, ELZ 599 f), може се мењати по нашим граматичким правилима: самураја, самурају, самурајем, итд. Реч карате, јапански рвачки спорт (ELZ 406 с), такође се може мењати: каратеа, каратеу, каратеом, итд. Слично и аикидо, јапанска борилачка вештина. Такође и реч цунами, океански таласи огромних размера који настају као последица земљотреса (MEP 647 с, ELZ 472). Овде би требало напоменути да се у издању ELZ - пише тсунами, већ 
смо раније објаснили предлог за транскрипцију $\boldsymbol{m} \boldsymbol{c}$. Исто тако, ова реч може да се мења као пл. тантум. Код речи харакири, начин самоубиства јапанских самураја и ари-стократских слојева (MEP 559 c, ELZ 367) не бисмо предложили мењање, а такође ни код речи камиказе, „божански ветар”, назив за јапанске пилоте-самоубице у Другом светском рату (MEP 187 b, ELZ 379). Ове две речи сматрамо да би боље било оставити непромењене, јер би њихово граматичко деклинирање изазвало одређене тешкоће.

\section{4. Однос савремене граматичке и правописне норме према адаптацији имена из јапанског језика у руском језику}

Јапански изговор је разнообразан, а различито писање појавило се због различитих путева усвајања речи у руском језику (на пример, Мицубиши, Тошиба, Мацушита - велике интернационалне компаније). Могуће је да су јапанска имена у руски језик ушла преко енглеског.

Transcribing a foreign name using katakana certainly has a mechanical, unimaginative aspect to it because (1) katakana-isation of foreign words and names is usually performed according to an established metod based on how English word or name sounds, or used to sound at one point, to the Japanese, and how this can be written down in rōmaji, and (2) many ordinary Western names, such as those of biblical or major historical characters, or celebrities, have their own conventionalised katakana-isation. This give us ジョン (Jon) for John, メアリー or マリ (Meari or Mari) for Mary, and アラン (Aran) for Alan. When they conflict with one another (that is, if the name does not sound to the translator like the conventionally katakana-ised version), the standard version tends to be more prized than other possible versions and is therefore adopted ... Regarding place names, as the chart indicates, most town names in fiction are transcribed according to the katakana-isation convention (which is common both in and out of translation) and the sound, regardless of their semantic meaning. Country and city names are also written in this way: ワイルドキャット (Wairudokyatto) for „Wildcat” as a place name (the Cat Who Knew a Cardinal, 1991, Lilian Jackson Braun, translated by Hada, 1995); アサペン・メドゥ (Aspen Medou) for „Aspen Meadow" (Nohara 2018: 121-122).

Предлажемо да у сваком конкретном случају треба погледати класични запис слова и пратити га.

\section{Изговор}

У савременом руском језику уобичила се пракса изговора јапанских речи оријентисана на то како се они пишу у руском језику. Практично је немогуће руским словима пренети звукове јапанске фонетике, нарочито ако је за запис јапанских речи било коришћено англојезично писмо. Представљање јапанске речи у руској транскрипцији спречавају често уочени случајеви писања јапанских речи руским словима, што се одражава на нетачан или погрешан запис тих речи.

За писање јапанских речи и властитих имена у Русији на крају XIX и почетку $\mathrm{XX}$ века користила се адаптирана за руски језик транскрипција Хепберна. У тридесетим годинама XX века ситуација се изменила и у Русији је почела да се користи руска транскрипција - киридзи или россиядзи, чија је прва варијанта била предложена 1917. године од стране изузетног лингвисте оријенталистике Јевгенија Дмитриевича Поливанова, коју често називају „систем Поливанова”, или „таблица Поливанова”. Савремена руска транскрипција представља посебну проширену 
транскрипцију Ј. Д. Поливанова и јединствени је документовани систем у Русији за запис изворно јапанских речи и властитих имена у јапанском језику (оних који се пишу на јапанском канђи писму и хирагани). Истовремено, са системом Поливанова били су предлагани и други системи, на пример, систем познатог јапанолога-практичара с почетка XX века Јевгенија Генриховича Спаљвина, који је живео и радио тридесетих година XX века у Харбину. Његов систем се заснивао на фонетској транскрипцији Хепберна. Транскрипција Спаљвина није била широко распрострањена и на крају XX века практично је била у потпуности истиснута из регуларне употребе од стране Поливановљеве транскрипције. Из Хепберновог система Поливанов је узео фонетику слогова $\boldsymbol{\phi y}$ и $\boldsymbol{m c y}$, записавши их као $\boldsymbol{\phi y}$ и $\boldsymbol{u} \boldsymbol{y}$, док је за остало углавном превео прописани ромађи у распоред руског писма (Сыятников 191: 54).

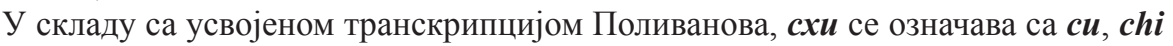
$-\boldsymbol{m u}, \boldsymbol{c h i}-\boldsymbol{m u}, \boldsymbol{j i}-\boldsymbol{\partial} \boldsymbol{u} \boldsymbol{e}, \boldsymbol{e}-\boldsymbol{\jmath}, \boldsymbol{j} \boldsymbol{o}-\ddot{\boldsymbol{e}}$, док се у транскрипцији Спаљвина, која се још увек може наћи у штампи, уместо $\boldsymbol{t i}$ користи $\boldsymbol{u} \boldsymbol{u}$, уместо э $-\boldsymbol{e}$, уместо $\ddot{\boldsymbol{e}}-\check{\boldsymbol{u}} \boldsymbol{o}$. У писању текстова обе транскрипције се често мешају, што и доводи до забуне (Сердюченко 1967: 225).

Систем Поливанова је формални систем транслитрације речи јапанског језика за оне који познају руски језик. За позајмљенице из јапанског језика основном формом требало би сматрати њихов запис у руском писму, а варијантом - њихов приказ средствима латиничног писма у сагласности са ортографским нормама тог језика. Добро знање јапанског језика (или знање терминологије на јапанском језику у области интересовања) дозвољава у већини случајева брзо и граматички исправно писање речи ћирилицом. Као последица природне разлике између фонетике руског и јапанског језика, понекад се јављају потешкоће у правилном запису засебних речи, које је, на крају, тешко сагледати. За термине јапанског порекла постоје у основи два извора јављања таквих транскрипционих варијанти: извесно неслагање у руској транскрипцији јапанских речи и неправилни превод латиничне транскрипције јапанске лексике у руску. Овде може помоћи само знање правила транскрипције (Неверов, Попов, Сыромятников, Фельдман, Цын 1970: 234).

Руска Поливановљева транскрипција је различита и од Хепбернове и од кунреј-ромађи. Већина преводилаца који нису јапанолози нису упознати са системом Поливанова и због тога транслитерацију са јапанског језика на руски раде по систему Хепберна, преводећи текстове са других језика. У том случају (при ћирилизацији латиничних јапанских речи по Хепберну), својственостима записа јавља се примена општеприхваћених правила транслитерације речи са енглеског језика. Због тога

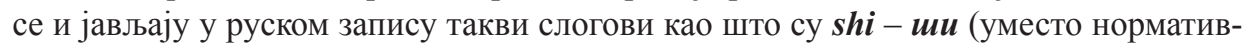
ног $\boldsymbol{c} \boldsymbol{u}), \boldsymbol{c h a}-\boldsymbol{u} \boldsymbol{a}($ уместо $\boldsymbol{m \boldsymbol { s }}$ ) итд. Тако, на пример, у Хепберновом систему слог $\boldsymbol{s} \boldsymbol{i}$

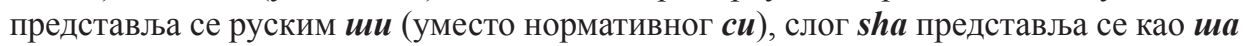

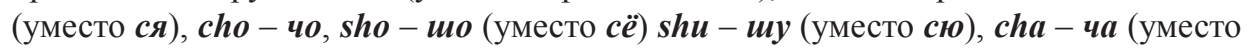

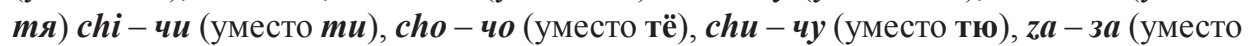
дза), ja - джа (уместо дэя) jo - джо (уместо дзё) tsu - mcy (уместо иу) nya - нья (уместо $\boldsymbol{\mu} \boldsymbol{s}), \boldsymbol{w o}-\boldsymbol{\sigma o}$ (уместо $\boldsymbol{o}$ ) итд.

У последње време може се уочити следећа тенденција: јапанска реч узима се у транскрипцији ромађи, а затим се врши транслитерација на руски језик. На руском 
језику то значи да се, на пример, уместо $\boldsymbol{c u}$ узима shi и пише $\boldsymbol{u} \boldsymbol{u}$. Иначе, руски слог „си” тачније приказује одговарајући слог јапанског језика од слога $\boldsymbol{и и}$. Због тога се потоњи у руском језику чита као [шы], који не постоји у јапанском језику. Треба напоменути, да знаци писма не одређују у пуној мери звучни састав језика. За тачније означавање звукова користи се фонетичка транскрипција.

За репродукцију страних имена и назива у руском језику предност се у већини случајева даје такозваној практичној транскрипцији, узимајући у обзир не само писану форму изворних речи већ и њихов изговор, као и историјски контекст (Неверов, Попов, Сыромятников, Фельдман, Цын 1970: 235).

Транслитерација је приказ словних знакова (како се пишу у изворном тексту), али то у јапанском језику због комбинације система записа (хирагана, катакана и канђи) није функционално (Неверов, Попов, Сыромятников, Фельдман, Цын 1970: 237).

Према томе, транслитерација у мањој мери предаје значај изговору, и у већој мери - запису, него транскрипција. Разлика између транслитерације и транскрипције је довољно условна, и оне се често мешају. У пракси, транслитерација се примењује ограничено.

Нека правила и примери ћирилизације јапанских речи

Ћирилични запис не одговара ни изговору ни транслитерацији јапанских речи, позајмљених из англојезичких извора. У вези са тим треба размотрити неколико правила записа речи јапанског језика посредством руског писма и укључити постојеће разлике између официјелног и Хепберновог система. У табели која следи наводе се неки од постојећих термина.

Јапанске речи и називе требало би представљати у складу са стандардном руском транскрипцијом јапанског језика киридзи, док се оне речи и називи који се користе у јапанском језику, а страног су порекла (за јапански језик), преводе у складу са њиховим читањем у руском (енглеском), а не у јапанском језику (на пример, асбеста не асубесуто, just-in-time (тачно на време), а не дзясўто-ин-тайму (Сердюченко 1967: 234).

\section{Означавање дужине самогласника}

У јапанском језику (приликом записа рачи као што су официјелни систем ромађи, као и Хепбернов систем) самогласници се разликују по дужини, која се означава цртицом изнад самогласника, знаком ^ изнад слова или двотачком након њега. То правило постоји само у научним радовима, уџбеницима и речницима и не односи се на издања популарне литературе. Дужина звука „ю” у официјелном систему ромађи често се означава словом , $\boldsymbol{y}^{\prime \prime}:$ kairyou, zidouka, seisou, а може и дуплирањем самогласника - hoosin, kairyoo (Сердюченко 1967: 234).

У киридзи систему дужина самогласника означава се цртом изнад слова: хоिсин, дзидокка или двотачком после слова: хо:син, дзидо:ка, кайре (видети таблицу).

У популарној литератури дужина самогласника може остати неозначена. По правилу, дужина самогласника се не означава приликом приказа јапанских властитих имена људи. На пример, Синго Сигэо у ромађи систему записује се Shingo Shigeo или Shingô Shigeo (Сердюченко 235: 1967). 


\begin{tabular}{|c|c|c|c|c|}
\hline \multicolumn{5}{|c|}{ Примена Һирилизащије пеких термина који се срећу у публикащијама о управљању } \\
\hline $\begin{array}{l}\text { Систем кунреј- } \\
\text { ромаши }\end{array}$ & $\begin{array}{l}\text { Хепбернов } \\
\text { систем }\end{array}$ & $\begin{array}{c}\text { Систем } \\
\text { Поливанова } \\
\text { (кириози) }\end{array}$ & $\begin{array}{l}\text { Канђи } \\
\text { (漢字) }\end{array}$ & $\begin{array}{l}\text { Хирагана } \\
\text { (ひらがฎ) }\end{array}$ \\
\hline Andon & Andon & Андон & 行灯 (フンドン) & あんどん \\
\hline Genba & Gemba & Гэмба & 現場 & げルば \\
\hline Genti genbutu & $\begin{array}{l}\text { Gienchi } \\
\text { gembutsu }\end{array}$ & $\begin{array}{l}\text { Гэнти } \\
\text { Гэмбуцу }\end{array}$ & 犋地球物 & けんちげんふつ \\
\hline Goesu & Goesu & Iоэс & $5 S$ & こえす \\
\hline Hansei & Hansei & Хансэй & 反许 & ははんせい \\
\hline IIcizyunka & Heijunka & Хойдзопика & 平售化 & へルじஆんか \\
\hline Hoosin kanri & Hoshin kanri & ХХ:син канри & 方針得理 & ほラし/かルり \\
\hline Zidouka & Jidoka & Дзидо:ка & 自儌仳 & じどうか \\
\hline Kairyou & Kairyo & Кайрё: & 改言 & がいりら \\
\hline Kaizen & Kaizen & Кайдзэн & 改语 & かいげん \\
\hline Kanban & Kamban & Камбаи & 在板 & かんばん \\
\hline $\begin{array}{l}\text { Mono to } \\
\text { zyouhou no } \\
\text { nagereeu }\end{array}$ & $\begin{array}{l}\text { Mono to } \\
\text { jouhou no } \\
\text { nagarczu }\end{array}$ & $\begin{array}{l}\text { Моно то } \\
\text { дзе:хо:-но } \\
\text { нагарэдзу }\end{array}$ & 物と古軲の流れ图 & ものとじようほうのながれず \\
\hline
\end{tabular}

Н И М

$\boldsymbol{H}$ испред $\boldsymbol{\sigma}, \boldsymbol{n}$ и $\boldsymbol{\boldsymbol { M }}$ у Хепберновом систему мења се са $\boldsymbol{\boldsymbol { M }}$. Аналогне измене дешавају се и у киридзи систему: $\boldsymbol{\boldsymbol { H }}$ испред $\boldsymbol{\sigma}, \boldsymbol{n}$ и $\boldsymbol{\boldsymbol { M }}$ пише се као $\boldsymbol{\boldsymbol { M }}$. На пример: kanban - kamban - камбан. Нажалост, у руској штампи ово правило се врло често нарушава.

Слоговно $\boldsymbol{\mu}$ испред самогласника се понекад означава као $\boldsymbol{\mu \boldsymbol { b }}$ како би се избегло мешање са слоговима реда $\boldsymbol{\mu a}$ : Гэнъити. Како би се разликовале такве речи при ћирилизацији, између $\boldsymbol{\boldsymbol { t }}$ и самогласника поставља се тврди знак. Препознати да ли је $\boldsymbol{\mu}$ слоговно или не у датом случају, у латиничној транскрипцији обично није могуће (мада се понекад слоговно $\boldsymbol{\mu}$ означава апострофом: Genïchi - Гэнъичи, ако изговарамо име по Хепберну (Прошина 2007: 128).

и

$\boldsymbol{И}$ после самогласника записује се као $\check{\boldsymbol{u}}$ : на пример, у имену Тай-ити, али Киитиро, где се после самогласника записјуе $\boldsymbol{u}$ а не $\check{\boldsymbol{u}}$, зато што овде постоји три корена Ки-ити-ро.

$\boldsymbol{И}$ после звука э често означава продужење тог самогласника и чешће од свега се пише као эй: на пример, хансэй (видети таблицу).

э и е

У складу са системом Поливанова, у јапанским речима не треба писати $\boldsymbol{e}$ него э. На пример, гэнти, а не генти. Исто тако, у неким случајевима тамо где треба да 
буде слово э, пише се $\boldsymbol{e}$, које боље одговара руском језику. Ако је на тој позицији, $\boldsymbol{e}$ се изговара [э] На пример, камикадзэ.

ё и й

Приликом записа ћирилицом речи Тоуота подједнако је прихватљива као и Тоёта и Тойота, али је кайрё при транскрипцији kairyou (видети таблицу). Географски називи Токио (Toukyou), Киото (Kyouto) и Иокогама (Yokohama) пишу се са ио и 2 (видети таблицу). Географски називи пишу се у складу са древном традицијом.

\section{ши, джи, чи итд.}

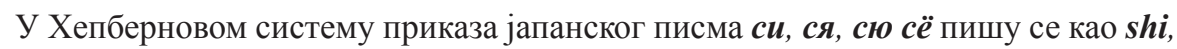
sha, shu, sho, а дзи, дзя, дзю и дзё-као ji, ja, ju и јо. Tu, mя, mю, mё- као chi, cha, $\boldsymbol{c h u}$, cho, што је блиско јапанском језику, али само за англојезични изговор.

Ови слогови се некад могу срести и у случају записа на руском језику јапанских имена и назива у нестандрадној транслитерацији (коришћење $\boldsymbol{ш и ~ у м е с т о ~} \boldsymbol{c u}, \boldsymbol{д ж и ~}$ уместо дзи и томе слично). Такви записи обично се појављују као покушај превода и транскрибовања неизворног јапанског оригинала, већ латиничног записа јапанских речи приликом превода са енглеског језика на руски. На пример, у речи jidôka (дзидока, tačnije дзидокка) слог $\boldsymbol{j i}$ (видети таблицу) приказује се као джи (уместо нормативног $\boldsymbol{\partial} \boldsymbol{u}$ ), али руски слог $\boldsymbol{д з и ~ т а ч н и ј е ~ п р е д с т а в љ а ~ о д г о в а р а ј у ћ и ~ с л о г ~ ј а п а н - ~}$ ског језика, од енглеског слога джи, зато што се потоњи у руском језику изговара джы, што у јапанском језику не постоји.

У запису ромађи (по Хепберну) слог chi у властитом имену Genichi Taguchi приказује се као чи (уместо нормативног ти приликом записа Geniti Taguti у државном ромаџи систему).

У речи heijunka (хэйдэюнка) слог $\boldsymbol{j i}$ (видети таблицу) приказује се као джу (уместо нормативног дзю).

Таквих примера коришћења ,американизама” у руској преведеној литератури можемо сусрести на много места (Крысин 2010: 358).

\section{IV. Закључак}

С обзиром на анализирани материјал и предложене транскрипцијске критеријуме, очигледно је да се досадашња неуједначеност норматива искључиво јавља као последица лошег познавања правила на којима се заснивају стране транскрипције јапанских имена које су нашим лексикографима служиле као изворници, односно као последица директне транслитерације са туђе транскрипције. Транслитерација туђих фонетских транскрипција или пак, погрешно тумачење њихових фонетских вредности доводило је до конфузије коју смо констатовали анализом корпуса и другог проучаваног материјала.

Иначе, што се тиче односа самих фонолошких система јапанског, српског и руског језика, нема ендогених разлога да ненормираних случајева уопште буде. Транскрипцијска схема коју у реферату предлажемо покрива све фонолошке облике 
познате у јапанским именима. Услед изузетне комплексности графијског система јапанског језика, препоручујемо, ипак, да стручњак-јапанолог увек буде консултован приликом одређивања транскрипционог облика јапанских имена. Ово важи и за случајеве када јапанска имена долазе у наш језик посредно, преко транскрипцијског система неког од светских језика, иако се надамо да ће овај рад у таквим случајевима бити од одређене помоћи. Нема основе веровати да је енглески систем, који нетачно преноси звуке страног језика, по нечему бољи од руског, такође, нетачног система. Тим пре, нема основе преводити енглески систем у руско писмо и тврдити да је то правилно.

Традиција приказа јапанских речи, заснована на транскрипцији Поливанова са својим јасним правилима, која је коначно прихваћена у руском језику тридесетих година прошлог века, била је потврђена у академским издањима, уџбеницима, речницима, посебним рецензијама и успешно је примењивана дуго година. Коришћење алтернативних ћириличних транскрипција - појава је обичне неписмености, која на крају доводи до значајне забуне у уму читаоца, и због тога је апсолутно недопустива.

У циљу унификације и избегавања забуне при запису јапанских речи и термина, требало би користити, формално признату у руском језику, таблицу Поливанова. Изузетак престављају речи јапанског порекла, као, на пример, иена, гейша, рикша, джиу-джитсу, и географски називи као Токио, Киото, Иокогама, Шикотан, који се пишу у складу са успостављеном и фиксираном нормом у реченицама, без обзира на то што такав запис није у складу са правилима Поливанова, а такође и властита имена на захтев носиоца тих имена.

Ако рачунамо да се у процесу превода и транскрибовања јапанских речи у њиховом латиничном запису користе распрострањене норме транскрипције латинице, тада се варијанте записа могу знатно разликовати међу собом у зависности од индивидуалних особености и нивоа учесника процеса. Као резултат, једни исти називи и термини (на пример, већ поменути термин каизен) у различитим изворима фиксирани су разним варијантама записа, па их је тешко сравнити, што води не само ка лингвистичком хаосу већ и забуни у терминологији.

Надамо се да је овај рад, ако и није сасвим јасно приказао како записивати јапанске речи коришћењем руске ћирилице, бар допринео у некој мери усклађивању у односу на питање коришћења практичне терминологије приликом писања јапанских речи на руском језику. 


\section{V. Индекс лексема}

\begin{tabular}{|c|c|}
\hline aikido & айкидо \\
\hline Akiko & акико \\
\hline Akira Kurosava & Акира Куросава \\
\hline cunami & цунами \\
\hline Cušima & Цусима \\
\hline Æiba & Тиба \\
\hline Đimu & Дэ \\
\hline džiudžicu & джиу-джитсу \\
\hline džudo & дэюдо \\
\hline Fuði & Фудзи \\
\hline Fuðita & Фудзита \\
\hline Fuðivara & Фудзивара \\
\hline fukuoka & Фукуока \\
\hline gejša & гейша \\
\hline Gocu & Гоцу \\
\hline harakiri & харакири \\
\hline hiragana & хирагана \\
\hline Hitaoi & хитаои \\
\hline Honšu & Хонсйю \\
\hline Iæikava Seiæi & Итикава Сэити \\
\hline Ihara Saikaku & Ихара Сайкаку \\
\hline Imazu & Имадзу \\
\hline Jaku & Яку \\
\hline jama & яма (гора) \\
\hline £apan & Япония \\
\hline Jasumi & Ясуми \\
\hline Jasuši & Ясуси \\
\hline Jošiaki & Ёсиаки \\
\hline Juki & Юки \\
\hline Juni & Юни \\
\hline Juriko & Юрико \\
\hline Juzo & Юдзо \\
\hline Kaoru & Kaopy \\
\hline kamikaze & камикадзе \\
\hline karate & карате/каратэ \\
\hline kava & кава \\
\hline
\end{tabular}




\begin{tabular}{|c|c|}
\hline kendo & кэндо \\
\hline kimono & кимоно \\
\hline Koèi & Кочи \\
\hline Koecu & Коэцу \\
\hline Kobajaši & Кобаяси \\
\hline Kobajaši Masaki & Кобаяси Масаки \\
\hline Kobajaši Takiði & Кобаяси Такидзи \\
\hline Kokure Goiæiro & Кокурё Гоитиро \\
\hline Kunihiro & Кунихиро \\
\hline Maæiko & Матико \\
\hline Maebaši & Маэбаси \\
\hline Makioka & Макиока \\
\hline Masaki & Масаки \\
\hline Meiði & Мэйдзи \\
\hline Miæiko & Митико \\
\hline Misava & Мисава \\
\hline Mito & Мито \\
\hline Muneo & Мунэо \\
\hline Muro Kjuso & Мypo \\
\hline Nacume Soseki & Нацумэ Сосэки \\
\hline Nara & Hapa \\
\hline Niigata & Ниигата \\
\hline Niko & Нико \\
\hline Okuni & Окуни \\
\hline Rašomon & Расёмон \\
\hline Rjunosuke Akutagava & Рюноскэ Акутагава \\
\hline sake & саке \\
\hline samuraj & самурай \\
\hline Sendai & Сендай/Сэндаэй \\
\hline Sumida & Сумида \\
\hline Sumidagava & Сумидагава \\
\hline Šizuoka & Сидзуока \\
\hline Tanaka Giiæi & Танака Гиити \\
\hline tenno & тэнно \\
\hline Tenrju & Тенрю/Тэнрю \\
\hline Tokio & Токио \\
\hline Tokuda Kuiæi & Токуда Кюити \\
\hline Tokutomi Kenðiro & Токутоми Кэндзиро \\
\hline Ueda & Уэда \\
\hline
\end{tabular}




\begin{tabular}{|l|}
\hline адзуки \\
\hline айдзобана \\
\hline айкидока \\
\hline айкидоги \\
\hline аниме \\
\hline аригато \\
\hline бенто \\
\hline \\
\hline боккэн \\
\hline бонза \\
\hline бонсай \\
\hline будо \\
\hline бунраку \\
\hline бусидо \\
\hline буцудан \\
\hline вака \\
\hline вакидзаси \\
\hline варибаси \\
\hline васаби \\
\hline ваи \\
\hline вата \\
\hline генмай \\
\hline гёдза \\
\hline го \\
\hline гуиноми \\
\hline гункан \\
\hline дайкон \\
\hline дан \\
\hline
\end{tabular}

\begin{tabular}{|c|}
\hline дзёсэй \\
\hline добуцу \\
\hline иваси \\
\hline икебана \\
\hline имари \\
\hline Йокогама \\
\hline кабуки \\
\hline какемоно \\
\hline Камакура \\
\hline караоке \\
\hline каккой \\
\hline камаэ \\
\hline ками \\
\hline каратеги \\
\hline Касио \\
\hline ката \\
\hline катана \\
\hline кемономими \\
\hline кендо \\
\hline кёкусинкай \\
\hline Киото \\
\hline киригами \\
\hline кобудзюцу \\
\hline коваии \\
\hline кодомо \\
\hline косплей \\
\hline Кофун \\
\hline кохай \\
\hline кусудама \\
\hline Кэнон (Киянон) \\
\hline
\end{tabular}




\begin{tabular}{|l|}
\hline Кюсю \\
\hline Мазда \\
\hline макидзуси \\
\hline манга \\
\hline мата не \\
\hline матча \\
\hline махо-сёдзё \\
\hline Мацусита (Панасоник) \\
\hline меха \\
\hline мидзухики \\
\hline мирин \\
\hline мисо \\
\hline Мицубиси \\
\hline Мэйдзи/Мейдзи \\
\hline Нара \\
\hline нарухудо \\
\hline нецке \\
\hline Никон \\
\hline Нинтендо \\
\hline Ниссан \\
\hline но \\
\hline нунтяки \\
\hline нэко \\
\hline ня \\
\hline Окинава \\
\hline оригами \\
\hline осибана \\
\hline патинко \\
\hline рамен \\
\hline
\end{tabular}

\begin{tabular}{|l|}
\hline сакура \\
\hline сатори \\
\hline семпай \\
\hline сетокан \\
\hline сёдзе \\
\hline сёдзи \\
\hline сёдо \\
\hline сёкен \\
\hline сёнен-ай \\
\hline Сикоку \\
\hline синто \\
\hline соба \\
\hline со ка \\
\hline Сони \\
\hline спокон \\
\hline Субару \\
\hline сугой \\
\hline Судзуки \\
\hline сумиэ \\
\hline сумо \\
\hline суси \\
\hline сэйнен \\
\hline сямисен \\
\hline тайфун \\
\hline тайхен \\
\hline татами \\
\hline темпура \\
\hline
\end{tabular}




\begin{tabular}{|l|}
\hline томоготи \\
\hline торин \\
\hline Тосиба \\
\hline удон \\
\hline Фудзи \\
\hline Фудзицу \\
\hline Фудзи-филм \\
\hline фусума \\
\hline футон \\
\hline хаси \\
\hline хасибукуро \\
\hline хасиоки \\
\hline
\end{tabular}

\begin{tabular}{|l|}
\hline Хейан \\
\hline хиндой \\
\hline Хиросима \\
\hline Хитати \\
\hline Хоккайдо \\
\hline Хонда \\
\hline Хонсю \\
\hline Хэйэй/Хейсей \\
\hline цунами \\
\hline Эдо \\
\hline Ямаха \\
\hline
\end{tabular}

\section{Лuтература}

Большой японско-русский словарь. В 2-х томах. Свыше 100000 сов. С приложением иероглифическога клю. Под редакцией Н. И. Конрада. Т. И А-Р. Сост. С. В. Неверов, К. А. Попов, Н. А. Сыромятников, Н. И. Фель М. С. Цын. - Москва: „Советская Энцикопедия”, 1970.

Габдуллина А. Х. „Лексические заимстования из японского языка в русский: когнитивно-прагматические собености и процесс ассимиляции." Вестник Челябинского государственного унивреситета. No. 2 8256. Филология. Искусствоведение. Вып. 62 (2012): стр. 12-16.

Крысин Л. П. Толковый словарь иноязычых слов. Москва: Эксмо, 2010.

Пешикан М., Јерковић Ј., Пижурица М. Правопис српског језика. Нови Сад: Матица српска, 2014.

Прошина 3. Г. Передача китайских, корейских и японских слов при переводе с английского языка на русский с русского языка на английский: теория и практика опосредованного перевода. Москва: АСТ: Восток - запад, 2007.

Сердюченко Г. П. Руссская транскрипция для языков зарубеженого Востока. Москва: Наука, 1967.

Лаврентьев Б. П., Немзер Л. А., Сыромяи Н. А и др. Современный русско-японский словарь. Москва: Живой язык, 2002.

Сыромятников Н. А. Система времен в новояапонском языке. Москва: Наука, 1971. Японский для начинающих. Токио: Gakken Co Ltd. SPB.: KARO, 2011.

Японский разговорник и словарь. Москва: Я 70, Живой язык, 2003.

Лютерйохан М. (сост.). Японский язык: 3 в 1: грамматика, разговорник, словарь. Москва: АСИ Астрель, 2007. 
Немзер Л. А., Сыромятников Н. А. (сост.). Японско-русский словарь. Под редакцией Н. И. Фельдман. С приложением очерка грамматики современного японского языка, составленного Н. И. Фель. 3. изд. Москва: Советская Энциклопедия, 1965.

Belić A. Osnovi istorije srpskohrvatskog jezika, 1, Fonetika, Beograd: Naučna knjiga, 1976.

Đimbo K., Kojo K. O. Fonetski elementi u japanskom. Tokio: Meiji Tosho Co., 1947.

Hatori, Širo, Oniron to seishoho (Fonologija i ortografija), Tokio, Kenkujsha, 1951.

Nohara K. Translating Popular Fiction, Embracing Otherness in Japanese Translations. New York: Oxford, 2018.

Miller R. A. The Japanese language. Tokyo: 1980.

Pavlović M. Uvod u nauku o jeziku. Beograd: 1973.

Rodić N. „Pravila i primeri transkripcije japanskih geografskih imena”, Naš jezik, XXII/3 (1976): str. 146-149.

Stanić M. Za kulturu jezika. Beograd: Zavod za udžbenike i naučna sredstva, 1973.

Tanizaiki Đ. Sestre Makioka. Beograd: Prosveta, 1972.

Terekava K. i dr. Kokugo Akusento Rosno (Akcentološko izučavanje japanskog jezika). Tokio: Hosei daigaku šupankjoku, 1951.

Tođo M. Kokugogaku šinko (Nova izučavanja u japanologiji). Tokio: 1968.

Ljiljana R. Marković

TRANSCRIBING JAPANESE ONOMASTICAL TERM INTO SERBIAN LANGUAGE

Summary

Although, in view of the high degree of mutual comaptibility existing between phonological systems of the two languages in question there does not seem to be anz room for emergence, or indeed, for survival of any endogenous transcriptional problems as such, these have, in actual fact arisen and perpetuated.

Reasons for this have been identified as mainly stemming from unenlightened and thoroughly inadequate transliterations from English, French, Russian and other national transcribing systems, themselves geared towards a phonetic rendering of Japanese names on view of the particular indigenous properties of their respective languages.

A transcription pattern more desirable from the point of view of our language has been outlined in this paper, with Japanese sounds rendered with the help of the Japanese officially recommended scientific transcription values, instead of the original Japanese writing symbols. This has been done with a view to avoiding the unneccessary technical difficulties.

The suggested transcription pattern would, it is hoped, help introduce orderliness and uniformity in the field of Japanese onomastics as transcribed and used in our language, with a proviso that we have here been concerned with the so-called broad transcription (mass-media etc), exclusively.

For, broad transcription is the only kind of transcription subject to various orthographic and other rules of the host language, and therefore, the only type of transcription of interest bearing in mind the proressed aims of this Conference.

Key words: Japanese language, Serbian language, Russian language, transcription, Japanese toponymy, proper name. 